\title{
The Relationship of Insulin-Like Growth Factor-I to Total Thyroxine in Normal and Low Birth Weight Infants
}

\author{
M. L. MITCHELL, R. J. HERMOS, M. FEINGOLD, AND A. C. MOSES \\ Massachusetts Department of Public Health [M.L.M., R.J.H.], Newborn Screening Program, State Laboratory \\ Institute, 305 South Street, Jamaica Plain, Massachusetts 02130, Outpatient Prenatal Care [M.F.]. Hertzliah, \\ Israel, and The Charles A. Dana Research Institute [A.C.M.], Harvard-Thorndike Laboratory of Beth Israel \\ Hospital, Department of Medicine, Harvard Medical School, Boston, Massachusetts 02215
}

\begin{abstract}
IGF-I concentrations were determined by RIA in eluates of dried blood collected on filter paper from infants who ranged in age from 3 to $21 \mathrm{~d}$. The infants were separated into normal $(>2.5 \mathrm{~kg})$ and low $(<2.5 \mathrm{~kg})$ birth wt groups and further subdivided on the basis of normal ( $>83.7 \mathrm{nmol} /$ liter) or low ( $<64.4 \mathrm{nmol} / \mathrm{liter})$ levels of thyroxine. Both the normal and low birth wt groups whose blood thyroxine was in the normal range had similar mean IGF-I values during the 1 st wk of life that were significantly higher $(p<0.05)$ than those of either the normal or low birth wt groups whose thyroxine concentrations were below normal. Infants older than 1 wk of age with normal birth wt and normal thyroxine levels had significantly greater $(p<0.05)$ mean IGF-I values than those of any of the other groups. Infants in the low birth wt-normal thyroxine group exhibited modest increases in IGF-I levels after the 1 st wk of life that were significantly greater $(p<$ 0.05 ) than those found in the low birth wt-low thyroxine infants. These studies have demonstrated that IGF-I concentration is correlated positively with total thyroxine and with birth wt and that the latter is confounded by the former. (Pediatr Res 25:336-338, 1989)
\end{abstract}

\section{Abbreviation}

\section{T4, Thyroxine}

Despite the intense interest in the potential growth-promoting role of IGF-I in the newborn during the perinatal period, the precise relationship of this peptide to growth and development remains unclear. Previous studies in preterm infants have demonstrated low concentrations of IGF-I compared to concentrations seen in adults but that nonetheless correlated positively with birth wt $(1,2)$. The determinant $(s)$ of these low concentrations of IGF-I in the preterm infant remains unresolved.

During the tenure of our newborn screening program for hypothyroidism, we have been impressed by substantial numbers of low birth wt infants who exhibit abnormally low levels of circulating total T4 but who have normal thyroid function, as reflected by normal free T4 and TSH measurements. In view of these observations, we wondered whether IGF-I concentrations also correlated with total T4; and if so, did this confound the relationship between IGF-I and low birth wt. Therefore, we measured IGF-I and T4 levels in blood specimens from normal

Received August 1, 1988; accepted November 15, 1988.

Correspondence M. L. Mitchell, M.D., State Laboratory Institute, 305 South Street, Jamaica Plain, MA 02130. and low birth wt infants. These studies have taken advantage of our recently described procedure for measuring IGF-I in whole blood collected on filter paper (3).

\section{MATERIALS AND METHODS}

Standardized filter paper forms (S\&S 903, Schleicher \& Schuell, Inc., Keene, NH) impregnated with whole capillary blood from 3- to 21-d-old infants were used in the study after all routine procedures had been completed by the Newborn Screening Laboratory. Specimens from newborns were randomly selected for analysis on the basis of T4 concentration and birth wt. Although the threshold for the low $\mathrm{T} 4$ range in our screening program is $83.7 \mathrm{nmol} /$ liter, we regard values between 64.4 and $83.7 \mathrm{nmol} /$ liter to be borderline low. For the purpose of this study, we elected to use only those specimens with unequivocally low T4 concentrations $(<64.4 \mathrm{nmol} /$ liter $)$. Because information on gestational age was unavailable from the forms, infants were separated into those of normal $(>2.5 \mathrm{~kg})$ and low $(<2.5 \mathrm{~kg})$ birth wt. Measurement of IGF-I was performed on filter paper blood specimens from 141 normal birth wt infants with normal T4 (>83.7 nmol/liter), 46 normal birth wt infants with low T4, 84 low birth wt infants with normal T4, and 92 low birth wt infants with low T4.

Filter paper specimens, when not in use, were stored at $-20^{\circ} \mathrm{C}$ in Ziplock (Dow Consumer Products, Inc., Indianapolis, IN 46268) plastic bags containing desiccant.

A detailed description of the procedure for the estimation of IGF-I can be found elsewhere (3); therefore, only the pertinent features will be described here. Duplicate $3.2 \mathrm{~mm}$ dried whole blood discs from each filter paper standard and blood specimen were eluted overnight into phosphate buffer containing rabbit antihuman IGF-I antibody, heparin, Tween-20, and ${ }^{125}$ I-IGF-I. The next $\mathrm{d}$, bound and free hormones were separated by the addition of goat antirabbit $\gamma$-globulin in $6 \%$ polyethylene glycol. After the supernate was discarded, the radioactivity in the precipitate was counted, and a standard curve was automatically constructed by on-line data reduction, which also calculated the values of the unknowns. The detection limit of IGF-I, described in our earlier report, was $0.05 \mathrm{U} / \mathrm{mL}$ of serum, and the $\mathrm{CV}$ less than $10 \%$. However, the sensitivity of the assay has been increased to a detection limit of $0.02 \mathrm{U} / \mathrm{mL}$ by repeated charcoal treatment or heat inactivation at neutral $\mathrm{pH}$ of the 0 standard to remove any endogenous IGF-I.

The values in the text and the table are reported as the mean $\pm \mathrm{SD}$; and stepwise regression analysis was performed using the Number Cruncher Statistical System 5.0. The statistical significance of the difference between the means was determined by 1 way ANOVA and the Duncan's New Multiple Range Test for multiple comparisons. 


\section{RESULTS}

ANOVA of the IGF-I values obtained during the 1st wk of life (between 3 to $7 \mathrm{~d}$ of age) revealed no significant difference by $\mathrm{d}$ of life within any of the subgroups. Hence the data were pooled and expressed as the mean of serum IGF-I values for each subgroup (Table 1). The results obtained on infants older than 1 wk of age also were pooled and expressed in the same format because of homogeneity of the data.

Serum IGF-I values during the 1st wk of life were similar in both the normal birth wt-normal $\mathrm{T} 4$ and low birth wt-normal T4 cohorts (0.09 and $0.10 \mathrm{U} / \mathrm{mL}$, respectively) and were significantly higher $(p<0.05)$ than those of either the normal birth wt-low T4 $(0.06 \mathrm{U} / \mathrm{mL})$ or the low birth wt-low T4 $(0.04 \mathrm{U} / \mathrm{mL})$ subgroups of infants. The importance of total $\mathrm{T} 4$ as an indicator of IGF-I concentration is evidenced by the significantly higher $(p<0.05)$ mean IGF-I value $(0.1 \mathrm{U} / \mathrm{mL})$ of the low birth wtnormal T4 subgroup when compared to the mean IGF-I value $(0.06 \mathrm{U} / \mathrm{mL})$ of the normal birth wt-low T4 infants, despite the greater mean birth wt of the latter. Total T4 seems to be an important variable in predicting the relative levels of IGF-I when $w t$ is held constant. This is supported by the significantly greater $(p<0.05)$ mean IGF-I concentration $(0.09 \mathrm{U} / \mathrm{mL})$ of the normal birth wt-normal $\mathrm{T} 4$ cohort in comparison with that of the normal birth wt-low T4 subgroup. Furthermore, the results of stepwise regression analysis indicated that IGF-I was more positively correlated with T4 than it was with birth wt (IGF-I and T4, $r=$ 0.38 ; IGF-I and birth wt, $r=0.16$ ).

The mean IGF-I levels of infants after the 1 st wk of life were significantly increased in the normal birth wt-normal T4 and low birth wt-normal T4 groups $(p<0.05)$ but not in the low birth wt-low T4 group. (The normal birth wt-low T4 cohort was not included because of the lack of specimens.) The most striking elevation was found in the normal birth wt-normal T4 subgroup, as evidenced by a mean IGF-I level $(0.36 \mathrm{U} / \mathrm{mL})$ that was significantly higher $(p<0.05)$ than that of either of the low birth wt subgroups. In the latter the mean IGF-I level of the low birth wt-normal T4 cohort $(0.14 \mathrm{U} / \mathrm{mL})$ remained significantly increased $(p<0.05)$ over that of the low birth wt-low T4 subgroup $(0.06 \mathrm{U} / \mathrm{mL})$.

\section{DISCUSSION}

Using a sensitive RIA, IGF-I levels were measured in capillary whole blood collected on filter paper from a cross-sectional population of infants who ranged in age from 3 to $21 \mathrm{~d}$. The four subgroups of infants who were tested during the 1st wk of life had mean IGF-I values that differed from those obtained on infants 2-3 wk of age. Moreover, during the 1st wk of life, both low and normal birth wt infants whose $\mathrm{T} 4$ concentrations were in the normal range had significantly higher IGF-I values than those infants matched for birth wt but whose $\mathrm{T} 4$ was below normal.

A strong positive correlation of birth wt with IGF-I had been reported previously by RIA of cord blood (4) and more recently from blood of term (5) and older infants (6). The present study confirms the positive relationship between birth wt and IGF-I concentrations in the newborn infant but shows that this association is confounded by the magnitude of the total T4. The correlation between total T4 and IGF-I levels presumably reflects a positive association between thyroxine-binding globulin (which we did not measure) and IGF-I concentrations. This does not necessarily imply a cause and effect relationship between the level of free or active T4 and the level of IGF-I. The total T4 could be a marker for events or factors, yet to be defined, that reflect the synthesis, secretion, or metabolism of IGF-I and/or its binding proteins. The fact that thyroxine-binding proteins in general (thyroxine-binding globulin, thyroxine-binding prealbumin, albumin), and most of the circulating IGF-I binding proteins are produced by the liver lends credence to the possibility that factors affecting liver protein synthesis could be involved. Under the conditions of this study, it is unlikely that thyroid secretion per se had any effect on IGF-I in the immediate newborn period. This conclusion is supported by studies in which the mean IGF-I values were similar for both hypothyroid and normal infants during the 1 st wk of life (7).

A major difference between infants 1 wk of age and those tested at 2-3 wk was the higher mean IGF-I levels of the latter. This was especially evident in the normal birth wt-normal T4 subgroup where the mean IGF-I concentration was seen to increase approximately 4 -fold. In contrast, the mean IGF-I concentration of the older infants in the low birth wt-normal T4 subgroup rose only slightly. The reason for the marked difference in IGF-I levels between the older infants in the normal birth wtnormal T4 and low birth wt subgroups is not entirely clear but could be related to the nutritional or health status of the infants. As a rule, we have found that those low birth wt infants whose blood specimens are not obtained until after the 1st wk of life are frequently suffering from a variety of problems, including. feeding difficulties, metabolic disorders, or sepsis.

Unfortunately, we were unable to obtain additional information regarding the health or nutritional status of the infants because of the structure of our screening program. However, the implications of the prolonged hospitalization of the low birth wi infants are self-evident, in view of the well-known effect that malnutrition and caloric deprivation have on lowering circulating levels of IGF-I $(8-10)$ and that illness has on reducing serum T4 concentrations (11). Caloric deprivation not only lowers IGFI but also alters thyroid hormone metabolism in human volunteers, as manifested by striking decreases in serum T3 without changes in $\mathrm{T} 4(12,13)$. However, the latter hormone is reduced in a variety of acute and chronic disorders (14); and because malnutrition is a frequent accompaniment of disease, it is very likely that both T3 and T4 are diminished. Until these confounding variables, and possibly others, can be sorted out, the reasons; for the lower IGF-I levels in low birth wt cohorts must remair. speculative.

Table 1. Mean values of results at different ages in subgroups

\begin{tabular}{|c|c|c|c|c|c|c|c|c|}
\hline \multirow[b]{2}{*}{ Wk of life } & \multicolumn{4}{|c|}{ Normal birth wt-normal T4 } & \multicolumn{4}{|c|}{ Normal birth wt-low T4 } \\
\hline & $n$ & $\begin{array}{c}\text { IGF-I } \\
(\mathrm{U} / \mathrm{mL})\end{array}$ & $\begin{array}{c}\mathrm{T} 4 \\
\text { (nmol/liter) }\end{array}$ & $\begin{array}{l}\text { Birth wt } \\
(\mathrm{kg})\end{array}$ & $n$ & $\begin{array}{c}\text { IGF-I } \\
(\mathrm{U} / \mathrm{mL})\end{array}$ & $\begin{array}{c}\mathrm{T} 4 \\
\text { (nmol/liter) }\end{array}$ & $\begin{array}{c}\text { Birth wt } \\
(\mathrm{kg})\end{array}$ \\
\hline 1 & 99 & $0.09 \pm 0.06$ & $111 \pm 14$ & $3.5 \pm 0.4$ & 46 & $0.06 \pm 0.05$ & $52 \pm 14$ & $3.4 \pm 0.5$ \\
\hline \multirow[t]{2}{*}{$2+3$} & 42 & $0.36 \pm 0.17$ & $118 \pm 15$ & $3.5 \pm 0.4$ & $*$ & & & \\
\hline & \multicolumn{4}{|c|}{ Low birth wt-normal T4 } & \multicolumn{4}{|c|}{ Low birth wt-low T4 } \\
\hline Wk of life & $n$ & $\begin{array}{c}\text { IGF-I } \\
(\mathrm{U} / \mathrm{mL})\end{array}$ & $\begin{array}{c}\mathrm{T} 4 \\
\text { (nmol/liter) }\end{array}$ & $\begin{array}{l}\text { Birth wt } \\
(\mathrm{kg})\end{array}$ & $n$ & $\begin{array}{c}\text { IGF-I } \\
(\mathrm{U} / \mathrm{mL})\end{array}$ & $\begin{array}{c}\mathrm{T} 4 \\
\text { (nmol/liter) }\end{array}$ & $\begin{array}{c}\text { Birth wt } \\
(\mathrm{kg})\end{array}$ \\
\hline 1 & 67 & $0.10 \pm 0.06$ & $118 \pm 22$ & $2.0 \pm 0.4$ & 52 & $0.04 \pm 0.03$ & $52 \pm 12$ & $1.2 \pm 0.4$ \\
\hline $2+3$ & 17 & $0.14 \pm 0.08$ & $108 \pm 17$ & $1.5 \pm 0.4$ & 40 & $0.06 \pm 0.07$ & $49 \pm 14$ & $1.1 \pm 0.4$ \\
\hline
\end{tabular}

* Insufficient numbers from this age group for statistical analysis. 
We recognize that the interpretation of our data is limited by virtue of the cross-sectional nature of the study and the absence of gestational age data. Nevertheless, the results showed that low T4 infants had lower IGF-I values, and by implication, suggested that there may be an association between IGF-I levels and neonatal "wellness." Clearly, this is a complex issue involving multiple determinants of the serum levels of both IGF-I and T4 such as hormone secretion, clearance, and binding proteins. A Iongitudinal study of neonates that evaluates these factors, coupled with infant diagnosis, nutritional state, and maturity, should help resolve many of the questions raised by the present study.

Acknowledgment. The IGF-I rabbit antibody was a gift of Drs. Louis Underwood and Judson J. Van Wyk, University of North Carolina at Chapel Hill, and distributed by the National Hormone and Pituitary Program. We are grateful to Ms. Ann J. E. Bennett for her assistance with the statistical analysis and to Ms. Deborah Frederick for her expertise in the preparation of the manuscript.

\section{REFERENCES}

1. Gluckman PD, Brinsmead MW 1976 Somatomedin in cord blood: relationship to gestational age and birth size. J Clin Endocrinol Metab 43:1378-1381

2. Foley TP Jr, DePhilip R, Perricelli A, Miller A 1980 Low somatomedin activity in cord serum from infants with intrauterine growth retardation. $J$ Pediatr 96:605-610

3. Mitchell ML, Hermos RJ, Moses AC 1987 Radioimmunoassay of somatome-
din-C in filter paper discs containing dried blood. Clin Chem 33:536-538

4. Bennett A, Wilson DM, Liu F, Nagashima R, Rosenfeld RG, Hintz RL 1983 Levels of insulin-like growth factors I and II in human cord blood. J Clin Endocrinol Mctab 57:609-612

5. Thieriot-Prevost G, Daffos F, Forestier F 1985 Serum somatomedin-C and bioassayable growth-promoting activity (thymidine activity) in appropriate and small-for-gestational-age human newborns. Acta Endocrinol (Copenh) 110:32-35.

6. Cassio A, Capelli M, Cacciari E, Cicognani A, Pirazzoli P, Righetti F, Ballardini D, Natali G, Zucchini S, Martelli E 1986 Somatomedin-C levels related to gestational age, birth weight and day of life. Eur J Pediatr 145:187-189

7. Mitchell ML, Hermos RJ, Moses AC 1987 Somatomedin-C/insulin-like growth factor- 1 in infants with congenital hypothyroidism during the first week of life. Clin Endocrinol 27:625-628

8. Grant DB, Hambley J, Becker D, Pimstone BL 1973 Reduced sulfation factor in undernourished children. Arch Dis Child 48:596-600

9. Hintz RL, Suskind R, Amatayakul K, Thanangkul O, Olson R 1978 Plasma somatomedin and growth hormone values in children with protein-calorie malnutrition. J Pediatr 92:153-156

10. Clemmons DR, Klibanski A, Underwood LE, McArthur JW, Ridgway EC Beitins IZ, Van Wyk JJ 1981 Reduction of plasma immunoreactive somatomedin- $C$ during fasting in humans. J Clin Endocrinol Metab 53:12471250

11. Zucker AR, Chernow B, Fields AI, Hung W, Burman KD 1985 Thyroid function in critically ill children. J Pediatr 107.552-554

12. Portnay $G$, O'Brian JT, Bush J, Vagenakis AG, Azizi F, Arky RM, Ingbar $\mathrm{SH}$ Braverman LE 1974 The effects of starvation on the concentration and binding of thyroxine and triiodothyronine in serum and on the response to TRH. J Clin Endocrinol Metab 39:191-194

13. Caufriez A, Golstein J, Lebrun P, Herchuelz A, Furlanetto R, Copinschi $G$ 1984 Relations between immunoreactive somatomedin $\mathrm{C}$, insulin and $\mathrm{T} 3$ patterns during fasting in obese subjects. Clin Endocrinol 20:65-70

14. Wartofsky L, Burman K 1982 Alterations in thyroid function in patients with systemic illness: the "euthyroid sick" syndrome. Endocr Rev 3:164-217 